\title{
Teori Kognitif dan Implikasinya Dalam Pembelajaran
}

\author{
Sutarto. M.Pd \\ Universitas Islam Negeri Imam Bonjol Padang
}

\begin{abstract}
Abstrak
Individu dapat mengembangkan pengetahuannya sendiri. Artinya adalah pengetahuan yang dimiliki oleh setiap individu dapat dibentuk oleh individu sendiri melalui interaksi dengan lingkungan yang terus-menerus dan selalu berubah. Dalam berinteraksi dengan lingkungan, individu mampu beradaptasi dan mengorganisasikan lingkungannya, sehingga terjadi perubahan dalam struktur kognitifnya, pengetahuan, wawasannya dan pemahamannya semakin berkembang. Individu juga mampu memodivikasi pengalaman yang diperoleh melalui lingkungan, sehingga melahirkan pengetahuan atau temuan-temuan baru. Oleh karena itu, proses pendidikan bukan hanya sekedar transfer of knowledge, tetapi juga bagaimana merangsang struktur kognitif inadividu mampu melahirkan pengetahuan dan temuan-temuan baru. Kedua, perlu adanya individualisasi dalam pembelajaran. Artinya, dalam proses pembelajaran, perlakuan terhadap individu harus didasarkan pada perkembangan kognitifnya. kunci keberhasilan dalam belajar terletak pada kebermaknaan bahan ajar yang diterima atau yang dipelajari oleh siswa. Dalam proses pembelajaran guru harus mampun memberikan sesuatu yang bermakna bagi siswa. Belajar dengan menghafal dan ceramah dapat menemukan sesuatu yang bermakna, asal dilakukan secara sistematis, menjelaskan dan menghubungkan antara konsep yang satu dengan konsep lainnya, menguhubungkan konsep yang baru dengan konsep yang telah dimiliki oleh siswa. Sebaliknya, belajar penemuan akan menjadi kurang bermakna, apa bila dilakukan dengan coba-coba dan tidak sistematis. Kedua, belajar bermakna akan berhasil apabila ada motivasi intrinsik dari dalam diri siswa. Dengan adanya motivasi intrinsik ini akan menumbuhkan minat dalam diri individu, dan menggerakkan individu untuk mempersiapkan diri untuk belajar, baik mempersiapkan diri secara fisik maupun psikis.
\end{abstract}

\section{A. Pendahuluan}

Secara bahasa kognitif berasal dari bahasa latin "Cogitare" artinya berfikir. ${ }^{1}$ Dalam Kamus Besar Bahasa Indonesia, kognitif berarti segala sesuatu yang berhubungan atau melibatkan kognisi, atau berdasarkan pengetahuan faktual yang empiris. ${ }^{2}$ Dalam pekembangan selanjutnya, istilah kognitif ini menjadi populer sebagai salah satu wilayah psikologi, baik psikologi perkembangan maupun psikologi pendidikan. Dalam psikologi, kognitif mencakup semua bentuk pengenalan yang meliputi setiap perilaku mental manusia yang berhubungan dengan masalah pengertian, pemahaman, perhatian, menyangka, mempertimbangkan, pengolahan informasi,

${ }^{1}$ Fauziah Nasution, Psikologi Umum: Buku Panduan untuk Fakultas Tarbiyah, (Medan: IAIN SU Press, 2011), h. 17

${ }^{2}$ Departemen Pendidikan dan Kebudayaan, Kamus Besar Bahasa Indonesia, (Jakarta: Balai Pustaka, 2002), h. 579 
pemecahan masalah, kesengajaan, membayangkan, memperkirakan, berpikir, keyakinan dan sebaganya. ${ }^{3}$

Dalam istilah pendidikan, kognitif disefinisikan sebagai satu teori di antara teori-teori belajar yang memahami bahwa belajar merupakan pengorganisasian aspek-aspek kognitif dan persepsi untuk memperoleh pemahaman. ${ }^{4}$ Dalam teori kognitif, tingkah laku seseorang ditentukan oleh persepsi dan pemahamannya tentang situasi yang berhubungan dengan tujuan. Perubahan tingkah laku seseorang sangat dipengaruhi oleh proses belajar dan berfikir internal yang terjadi selama proses belajar. ${ }^{5}$

Teori belajar kognitif merupakan suatu teori belajar yang lebih mementingkan proses belajar daripada hasil belajar. Teori kognitf pada awalnya dikemukakan oleh Dewwy, dilanjutkan oleh Jean Piaget, Kohlberg, Damon, Mosher, Perry dan lain-lain, ${ }^{6}$ yang membicarakan tentang perkembangan kognitif dalam kaitannya dengan belajar. Kemudian dilanjutkan oleh Jerome Bruner, David Asubel, Chr. Von Ehrenfels Koffka, Kohler, Wertheimer dan sebagainya. ${ }^{7}$ Bagi penganut aliran ini, belajar tidak sekedar melibatkan hubungan antar stimulus dan respons. Namun lebih dari itu, belajar melibatkan proses berpikir yang sangat kompleks. Belajar melibatkan prinsip-prinsip dasar psikologi, yaitu belajar aktif, belajar lewat interaksi sosial dan lewat pengalaman sendiri.

Teori belajar kognitif muncul dilatarbelakangi oleh ada beberapa ahli yang belum merasa puas terhadap penemuan-penemuan para ahli sebelumnya mengenai belajar, sebagaimana dikemukakan oleh teori Behavior, yang menekankan pada hubungan stimulus-responsreinforcement. Munculnya teori kognitif merupakan wujud nyata dari kritik terhadap teori Behavior yang dianggap terlalu naïf, sederhana, tidak masuk akal dan sulit dipertanggungjawabkan secara psikologis. ${ }^{8}$ Menurut paham kognitif, tingkah laku seseorang tidak hanya dikontrol oleh reward (ganjaran) dan reinforcement (penguatan). Tingkahlaku seseorang senantiasa didasarkan pada kognisi, yaitu tindakan untuk mengenal atau memikirkan situasi di mana tingkahlaku itu terjadi. Dalam situasi belajar, seseorang terlibat langsung dalam situasi itu dan memperoleh pemahaman atau insight untuk pemecahan masalah. Paham kognitifis berpandangan bahwa, tingkahlaku seseorang sangat tergantung pada pemahaman atau insight terhadap hubungan-hubungan yang ada di dalam suatu situasi. ${ }^{9}$

Menurut teori kognitif, ilmu pengetahuan dibangun dalam diri seorang individu melalui proses interaksi yang berkesinambungan dengan

\footnotetext{
${ }^{3}$ Mimi Suharti, Perkembangan Peserta Didik, (Padang: IAIN IB Press, 2011), h. 28

${ }^{4}$ Hendra Harmi, Teori Belajar dan Pembelajaran, (Curup: LP2 STAIN, 2010), h. 70

5 Haryanto Suyono, Belajar dan Pembelajaran, (Bandung: Remaja Rosdakarya, 2011), h.

${ }^{6}$ Sjarkawi, Pembentukan Kepribadian Anak: Peran Moral, Intelektual dan Sosial sebagai Wujud Integritas Membangun Jati Diri, (Jakarta: Bumi Aksara, 2006), h. 45

${ }^{7}$ Mulyono Abdurrahman, Pendidikan bagi Anak Berkesulitan Belajar, (Jakarta: Rineka Cipta, 2003), h. 34

${ }^{8}$ Ahmad Muzakir dan Joko Sutrisno, Psikologi Pendidikan: untuk Fakultas Tarbuyah Komponen MKBK, (Jakarta: Pustaka Setia, 1997), h. 47

${ }^{9}$ Westy Soemanto. Psikologi Pendidikan, (Jakarta : Rineka Cipta, 2003), h. 127 
lingkungan. ${ }^{10}$ Proses ini tidak berjalan secara terpisah-pisah, tetapi melalui proses yang mengalir, bersambung-sambung dan menyeluruh. Ibarat seseorang yang memainkan alat musik, orang tidak akan bisa alat memainkan musik tanpa memahami terlebih not-not balok yang terpampang pada portitur sebagai informasi yang saling lepas dan berdiri sendiri, tetapi sebagai satu kesatuan yang secara utuh masuk pikiran dan perasaannya.

Dalam praktik, teori ini terwujud dalam "tahap-tahap perkembangan" yang diusulkan oleh Jean Piaget, "belajar bermakna" oleh Ausubel, dan "belajar penemuan" (Discovery Learning) oleh Jerome Bruner, belajar pemahaman (insight) dan sebagainya. Kesemuanya itu akan dibahas dalam makalah ini dengan menggunakan pendekatan library research dengan teknik study dokumentasi. Maksudnya adalah data berkaitan dengan teori kognitif dikumpulkan dari buku-buku, jurnal dan karya iilmiah dan sebagainya. Kemudian dianalisis dengan pendekatan reflektif thinking, yaitu kombinasi antara pendekatan induksi dan deduksi.

\section{B. Teori Kognitif dalam Pembelajaran}

1. Belajar dalam Presfektif Teori Kognitif

Terdapat banyak pandangan tentang belajar, sehingga muncul berbagai teori belajar. Antara teori yang satu dengan teori lainnya berbeda-beda dalam mendefinisikan belajar. Teori belajar hadir dan muncul pada dasarnya disebabkan oleh para ahli Psikologi belum puas dengan penjelasan teori-teori yang terdahulu tentang belajar. Di antara teori belajar yang sangat terkenal adalah teori behavior dan teori kognitif.

Menurut teori behavior, segala kejadian di lingkungan sangat mempengaruhi prilaku seseorang dan akan memberikan pengalaman tertentu dalam dirinya. Oleh karena itu, belajar menurut teori behavior adalah perubahan tingkahlaku sebagai akibat dari interaksi individu dengan lingkungannya, interaksi tersebut merupakan hasil dari conditioning melalui S-R (stimulus-respons). ${ }^{11}$ Seseorang dikatakan telah belajar, apabila menunjukkan perubahan tingkah laku dari stimulus yang diterimanya. Abu Ahmadi dan Widodo Supriyono mengemukakan, perubahan tingkah laku tersebut dapat diamati dengan indera manusia dan langsung tertuang dalam tingkah lakuknya. ${ }^{12}$ Individu belum dikatakan belajar, apabila belum terjadi perubahan tingkah laku individu.

Berbeda denga teori kognitif, belajar bukan hanya sekedar melibatkan hubungan stimulus dan respon, tetapi belajar pada hakekatnya melibatkan proses berfikir yang sangat kompleks. Belajar adalah usaha mengaitkan pengetahuan baru ke dalam struktur berfikir yang sudah dimiliki individu, sehingga membentuk struktur kognitif baru yang lebih

${ }^{10}$ Margaret Gredler \& E. Bell, Learning And Instruction Theory Into Practice. Mc.Milan Publishing Company, diterjemahkan oleh Munandir, (Jakarta: Rajawali. 1991), h. 278

${ }^{11}$ M. Ngalim Purwanto, Psikologi Pendidikan, (Bandung: PT. Remaja Rosdakarya, 2004),

${ }^{12}$ Abu Ahmad \& Widodo Supriyono, Psikologi Belajar, (Jakarta : Rineka Cipta, 1991), h. 121 
mantap sebagai hasil belajar. ${ }^{13}$ Teori kognitif juga beranggapan bahwa, tingkah laku seseorang selalu didasarkan pada kognisi, yaitu suatu perbuatan atau tingkahlaku individu ditentukan oleh persepsi atau pemahamannya tentang diri dan situasi yang berhubungan dengan tujuan yang ingin dicapai. ${ }^{14}$ Dalam teori kognitif, belajar pada prinsipnya adalah perubahan persepsi dan pemahaman yang tidak selalu dapat dilihat sebagai perubahan tingkah laku yang kongkrit. Di sisi lain, teori belajar kognitif lebih menekankan bahwa, belajar merupakan suatu proses yang terjadi dalam akal pikiran manusia. Seperti diungkapkan oleh Winkel bahwa "belajar adalah suatu aktivitas mental atau psikis yang berlangsung dalam interaksi aktif dengan lingkungan yang menghasilkan perubahanperubahan dalam pengetahuan, pemahaman, ketrampilan, nilai dan sikap, perubahan itu bersifat relatif dan berbekas". ${ }^{15}$

Berdasarkan beberapa pengertian di atas, dapat diketahui bahwa belajar menurut teori kognitif adalah suatu proses atau usaha yang melibatkan aktivitas mental yang terjadi dalam diri manusia sebagai akibat dari proses interaksi aktif dengan lingkungannya untuk memperoleh suatu perubahan dalam bentuk pengetahuan, pemahaman, tingkah laku, keterampilan, nilai dan sikap yang bersifat relatif dan berbekas. Misalnya, seseorang mengamati sesuatu ketika dalam perjalanan. Dalam pengamatan tersebut terjadi aktifitas mental. Kemudian ia menceritakan pengalaman tersebut kepada temannya. Ketika dia menceritakan pengalamannya selama dalam perjalanan, dia tidak dapat menghadirkan objek-objek yang pernah dilihatnya selama dalam perjalanan itu, dia hanya dapat menggambarkan semua objek itu dalam bentuk kata-kata atau kalimat. Maka dengan demikian, telah terjadi proses belajar, dan terjadi perubahan terutama terhadap pengetahuan dan pemahaman. Jika pengetahuan dan pemahaman tersebut mengakibatkan perubahan sikap, maka telah terjadi perubahan sikap, dan seterusnya.

2. Beberapa Teori Kognitif: Tokoh dan Pemikirannya

a. Teori Kognitif menurut Jean Piaget

1). Gambaran umum tentang Teori Kognitif Jean Piaget

Jean Piaget (1896-1980) lahir di Swiss. Pada awal mulanya ia ahli biologi, dan dalam usia 21 tahun sudah meraih gelar doktor. Ia telah berhasil menulis lebih dari 30 buku bermutu, yang bertemakan perkembangan anak dan kognitif. $^{16}$ Pengaruh pemikiran Jean Piagert baru mempengaruhi masyarakat, seperti di Amirika Serikat, Kanada, dan Australia baru sekitar tahun 1950-an. Menurut Bruno (dalam Muhibin Syah), hal ini disebabkan karena terlalu kuatnya cengkeraman aliran Behaviorisme gagasan Watson $(1878-1958) .^{17}$

\footnotetext{
${ }^{13}$ Yusuf, dkk, Konsep Dasar dan Pengelolaan Kegiatan Belajar Mengajar, (Bandung: Andira, 1993), h. 49

${ }^{14}$ Muhaimin, Paradigma Pendidikan Islam: Upaya Mengefektifkan Pendidkan Agama Islam di Sekolah, (Bandung: PT. Remaja Rosdakarya, 2012), h. 198

${ }^{15}$ WS. Wingkel, Psikologi Pendidikan, (Jakarta: Gramedia, 1996), h. 53

16 Muhibbin Syah, Psikologi Pendidikan: Suatu Pendekatan Baru, (Bandung: Remaja Rosdakarya, 2010), h. 66

${ }^{17}$ Ibid., h. 67
} 
2). Belajar menurut Teori Kognitif Jean Piaget

Jean Piaget mengemukakan bahwa proses belajar akan terjadi apabila ada aktivitas individu berinteraksi dengan lingkungan sosial dan lingkungan fisiknya. ${ }^{18}$ Pertumbuhan dan perkembangan individu merupakan suatu proses sosial. Individu tidak berinteraksi dengan lingkungan fisiknya sebagai suatu individu terikat, tetapi sebagai bagian dari kelompok sosial. Akibatnya lingkungan sosialnya berada di antara individu dengan lingkungan fisiknya. Interaksi Individu dengan orang lain memainkan peranan penting dalam mengembangkan pandangannya terhadap alam. ${ }^{19}$ Melalui pertukaran ide-ide dengan orang lain, individu yang tadinya memiliki pandangan subyektif terhadap sesuatu yang diamatinya akan berubah pandangannya menjadi obyektif.

Piaget mengemukakan bahwa, perkembangan kognitif memiliki peran yang sangat penting dalam proses belajar. Perkembangan kognitif pada dasarnya merupakan proses mental. Proses mental tersebut pada hakekatnya merupakan perkembangan kemampuan penalaran logis (development of ability to respon logically). ${ }^{20}$ Bagi Piaget, berfikir dalam proses mental tersebut jauh lebih penting dari sekedar mengerti. ${ }^{21}$ Semakin bertambah umur seseorang, maka semakin kompleks susunan sel syarafnya dan semakin meningkat pula kemampuan kognitifnya. ${ }^{22}$

Proses perkembangan mental bersifat universal dalam tahapan yang umumnya sama, namun dengan berbagai cara ditemukan adanya perbedaan penampilan kognitif pada tiap kelompok manusia. ${ }^{23}$ Sistem persekolahan dan keadaan sosial ekonomi dapat mempengaruhi terjadinya perbedaan penampilan dan perkembangan kognitif pada individu, demikian pula dengan budaya, sisitem nilai dan harapan masyarakat masing-masing. ${ }^{24}$

\section{3).Tahap-tahap Perkembangan Kognitif Menurut Jean Piaget}

Menurut Piaget, pengetahuan dibentuk oleh individu melalui interaksi secara terus menerus dengan lingkungan. ${ }^{25}$ Ada empat tahap perkembangan kognitif menurut Piaget, yaitu :

${ }^{18}$ Al Rasyidin \& Wahyudin Nur Nasution, Teori Belajar dan Pembelajaran, (Medan: Perdana Publishing, 2011), h. 30

${ }^{19}$ Mustakim dan Abdul Wahab, Psikologi Pendidikan, (Jakarta: Rineka Cipta, 2003), h. 34

${ }^{20}$ Endang Purwanti Nur Widodo, Perkembangan Peserta Didik, (Malang: UMM Press, 2005), h. 40

${ }^{21}$ Agus Suyanto, Psikologi Perkembangan, (Jakarta: PT. Aksara Baru, 1990), h. 49

${ }^{22}$ Muhaimin, Paradigma Pendidikan Islam: Upaya Mengefektifkan Pendidkan Agama Islam di Sekolah...Op. Cit., h. 199

${ }^{23}$ Hartono. A dan Sunarto, Perkembangan Peserta Didik, (Jakarta: Direktorat Jendral Pendidikan Tinggi, Depdikbud, 1992), h. 72

${ }^{24}$ Elizabeth B. Hurlock, Psikologi Perkembangan: Suatu Pendekatan Sepanjang Rentang Kehidupan Manusia, (Jakarta: Erlangga, 1992), h. 42

${ }^{25}$ Dimyati dan Muljiono, Belajar dan Pembelajaran, (Jakarta: Rineka Cipta, 2006), h. 13 
a).Tahap sensorimotor (usia 0-2 tahun). ${ }^{26}$ individu memahami sesuatu atau tentang dunia dengan mengkoordinasikan pengalaman-pengalaman sensoris, (seperti melihat, dan mendengar) dan dengan tindakan-tindakan motorik fisik. ${ }^{27}$ Dengan kata lain, pada usia ini individu dalam memahami sesuatu yang berada di luar dirinya melalui gerakan, suara atau tindakan yang dapat diamati atau dirasakan oleh alat inderanya. Selanjutnya sedikit demi sedikit individu mengembangkan kemampuannya untuk membedakan dirinya dengan bendabenda lain.

b) Tahap pra-operasional (usia 2-7 tahun). ${ }^{28}$ Individu mulai melukiskan dunia melalui tingkah laku dan kata-kata. Tetapi belum mampu untuk melakukan operasi, yaitu melakukan tindakan mental yang diinternalisasikan atau melakukan tindakan mental terhadap apa yang dilakukan sebelumnya secara fisik. ${ }^{29}$ Pada usia ini individu mulai memiliki kecakapan motorik untuk melakukan sesuatu dari apa yang dilihat dan didengar, tetapi belum mampu memahami secara mental (makna atau hakekat) terhadap apa yang dilakuaknnya tersebut. ${ }^{30}$

c) Tahap operasional konkret (usia 7-11 tahun). ${ }^{31}$ Individu mulai berpikir secara logis tentang kejadian-kejadian yang bersifat konkret. ${ }^{32}$ Individu sudah dapat membedakan benda yang sama dalam kondisi yang berbeda. ${ }^{33}$

d) Tahap operasional formal (11 tahun ke atas). ${ }^{34}$ Sementara Salvin menjelaskan bahwa pada operasional formal terjadi pada usia 11 sampai dewasa awal. ${ }^{35}$ Pada masa ini individu mulai memasuki dunia "kemungkinan" dari dunia yang sebenarnya atau individu mengalami perkembangan penalaran abstrak. ${ }^{36}$ Individu dapat berpikir secara abstrak, lebih logis dan idealis. ${ }^{37}$

Kecepatan perkembangan setiap individu melalui urutan, dan setiap tahap tersebut berbeda dan tidak ada individu yang melompati salah satu dari tahap tersebut. Setiap tahap ditandai

\footnotetext{
${ }^{26}$ J. W. Santrock, Perkembangan Masa Hidup Jilid I, (Jakarta, Erlangga : 2004), h. 44

${ }^{27}$ Ibid.

${ }^{28}$ Ibid., h. 45

${ }^{29}$ Syamsu Yusuf LN, Psikologi Perkembangan Anak dan Remaja, (Jakarta, Remaja Rosdakarya, 2008), h. 36

${ }^{30}$ Kartini Kartono, Psikologi Anak (Psikologi Perkembangan), (Bandung: Mondar Maju,
} 1995), h. 52

${ }^{31}$ J. W. Santrock, Perkembangan Masa Hidup Jilid I...,.Op. Cit., h. 46 2005), h. 64

32 Abu Ahmadi dan Munawar Sholeh, Psikologi Perkembangan, (Jakarta : Rineka Cipta,

${ }^{33}$ Desmita, Psikologi Perkembangan, (Bandung: PT. Remaja Rosdakarya, 2008), h. 47

${ }^{34}$ J. W. Santrock, Perkembangan Masa Hidup Jilid I....,.Op. Cit., h. 47

35 Robert E Slaven, Educational Psycology: Theory and Practice. (America: The United States of America, 2011), h. 14

36 Winfred F. Hill, Theories of Learning (Teori-teori dalam Pembelajaran,Konsepsi, Komparasi, dan Signifikan, (Bandung: Nusa Media, 2011), h. 161

${ }^{37}$ Dewi Purnama Sari, Psikologi Perkembangan Anak, (Curup: LP2 STAIN Curup, 2010), h. 31 
dengan munculnya kemampuan-kemampuan intelektual baru yang memungkinkan orang memahami dunia dengan cara yang semakin kompleks. ${ }^{38}$ Hal ini berarti bahwa semakin bertambah umur seseorang, maka semakin kompleks susunan sel syarafnya dan semakin meningkat pula kemampuan kognitifnya.

Menurut Peaget, ada tiga proses yang mendasari perkembangan individu yaitu asimilasi, akomodasi, dan ekuilibrasi. ${ }^{39}$ Asimilasi ialah pemaduan data atau informasi baru dengan struktur kognitif yang ada, akomodasi ialah penyesuaian struktur kognitif yang sudah ada dengan situasi baru, dan ekuilibrasi ialah penyesuaian secara seimbang, terus-menerus yang dilakukan antara asimilasi dan akomodasi. ${ }^{40}$

Asimilasi, akomodasi dan ekuilibrasi sudah berlangsung sejak kehidupan pada masa bayi. Pada saat seseorang tumbuh menjadi dewasa, akan mengalami adaptasi biologis dengan lingkungannya dan akan menyebabkan adanya perubahanperubahan kualitatif dalam struktur kognitifnya. Apabila seseorang menerima informasi atau pengalaman baru maka informasi tersebut akan dimodifikasi hingga sesuai dengan struktur kognitif yang dimilikinya. Proses ini disebut asimilasi. Sebaliknya, apabila struktur kognitifnya yang harus disesuaikan dengan informasi yang diterima, maka proses ini disebut akomodasi. Asimilasi dan akomodasi akan terjadi apabila terjadi konflik koginitif atau suatu ketidakseimbangan antara apa yang telah diketahui dengan apa yang dilihat atau dialaminya sekarang. Adaptasi akan terjadi apa bila telah terjadi keseimbangan dalam struktur kognitif. Proses penyesuaian tersebut terjadi secara seimbang dan terus-menerus dilakukan secara asimilasi dan akomodasi, itulah yang dinamakan ekuilibrasi.

4).Implikasi Teori Kognitif Piaget dalam Pembelajaran

Ada beberapa hal penting yang diambil terkait teori kognitif sebagaimana dikemukakan oleh Piaget, diantaranya adalah :

a). Individu dapat mengembangkan pengetahuannya sendiri

Yang menjadi titik pusat dari teori belajar kognitif Piaget ialah individu mampu mengalami kemajuan tingkat perkembangan kognitif atau pengetahuan ke tingkat yang lebih tinggi. Maksudnya adalah pengetahuan yang dimiliki oleh setiap individu dapat dibentuk dan dikembangkan oleh individu sendiri melalui interaksi dengan lingkungan yang terus-menerus dan selalu berubah. Dalam berinteraksi dengan lingkungan tersebut, individu mampu beradaptasi dan mengorganisasikan lingkungannya, sehingga terjadi perubahan dalam struktur kognitifnya, pengetahuan, wawasan dan

\footnotetext{
${ }^{38}$ Trianto, Model Pembelajaran Terpadu dalam Teori dan Praktek, (Jakarta: Prestasi Pustaka Publisher, 2007), h. 22

${ }^{39}$ Margaret Gredler \& E. Bell, Learning And Instruction Theory Into Practice...., Op. Cit., h. 311

${ }^{40}$ Ibid. 
pemahamannya semakin berkembang. Atau dengan kata lain, individu dapat pintar dengan belajar sendiri dari lingkungannya.

Walaupun demikian, pengetahuan yang diperoleh individu melalui interaksi dengan lingkungan, adakalanya tidak persis sama dengan apa yang diperoleh dari lingkungan itu. Individu mampu mengembangkan pengetahuannya sendiri, mampu memodivikasi pengalaman yang diperoleh dari lingkungan, sehingga melahirkan pengetahuan atau temuantemuan baru. Hal ini terbukti banyak ilmuwan yang menghasilkan temuan-temuan baru yang selama ini tidak dipelajari di bangku sekolah. Oleh karena itu, proses pendidikan bukan hanya sekedar transfer of knowledge, tetapi juga bagaimana merangsang struktur kognitif inadividu sehingga mampu melahirkan pengetahuan dan temuan-temuan baru.

b). Individualisasi dalam pembelajaran

Dalam proses pembelajaran, perlakuan terhadap individu harus didasarkan pada perkembangan kognitifnya. Atau dengan kata lain, dalam proses pembelajaran harus disesuaikan dengan tingkat perkembangan individu. Belajar akan lebih berhasil apabila disesuaikan dengan tahap perkembangan kognitif peserta didik. Hal ini disebabkan karena setiap tahap perkembangan kognitif memiliki karakteristik berbeda-beda. Susunan saraf seorang akan semakin kompleks seiring dengan bertambahnya umur. Hal ini memungkinkan kemampuannya semakin meningkat. ${ }^{41}$ Oleh karena itu, dalam proses belajar seseorang akan mengikuti pola dan tahap perkembangan tertentu sesuai dengan umurnya. Penjenjangan ini bersifat hirarki, yaitu melalui tahap-tahap tertentu sesuai dengan umurnya. Seseorang tidak dapat mempelajari sesuatu yang di luar kemampuan kognitifnya. ${ }^{42}$

Tingkat perkembangan peserta didik harus dijadikan dasar pertimbangan guru dalam menyusun struktur dan urutan mata pelajaran di dalam kurikulum. Hunt (dalam Abu Ahmadi dan Widodo Supriyono) mempraktekkan di dalam program pendidikan TK yang menekankan pada perkembangan sensorimotoris dan praoperasional. ${ }^{43}$ Misalnya: belajar menggambar, mengenal benda, menghitung dan sebagainya. Seorang guru yang bila tidak memperhatikan tahapan-tahapan perkembangan kognitif, maka akan cenderung menyulitkan siswa. Contoh lain, mengajarkan konsep-konsep abstrak tentang shalat kepada sekelompok siswa kelas dua SD, tanpa adanya usaha untuk mengkongkretkan konsep-konsep tersebut,

${ }^{41}$ Elida Prayitno, Perkembangan Peserta Didik, (Jakarta : Dirjen Dikti, 1991), h. 81

${ }^{42}$ Al Rasyidin \& Wahyudin Nur Nasution, Teori Belajar dan pembelajaran..., Op. Cit., h.

43 Abu Ahmad \& Widodo Supriyono, Psikologi Belajar..., Op. Cit., h. 216 
tidak hanya sia-sia, tetapi justru akan lebih membingungkan siswa. $^{44}$

Dalam proses pembelajaran juga harus memperhatikan tingkat perkembangan peserta didik. Bahasa dan cara berfikir anak berbeda dengan orang dewasa. Oleh karena itu dalam proses pembelajaran, guru harus menggunakan bahasa yang sesuai dengan cara berfikir anak.

b. Teori Belajar J. S Bruner (Belajar Penamuan)

1).Gambaran Umum tentang Teori Belajar J. S Bruner

Bruner yang memiliki nama lengkap Jerome S. Bruner, seorang ahli psikologi perkembangan dan psikologi belajar kognitif, lahir tahun 1915 di New York City, dan lulusan dari Universitas Harvard, Amerika Serikat. ${ }^{45}$ Bruner telah mempelopori aliran psikologi kognitif yang memberi dorongan agar pendidikan memberikan perhatian pada pentingnya pengembangan berfikir, dengan cara mementingkan partisipasi aktif individu dan mengenal adanya perbedaan kemampuan untuk melakukan eksplorasi dan penemuan-penemuan baru ${ }^{46}$

Teori kognisi J. S Bruner menekankan pada cara individu mengorganisasikan apa yang telah dialami dan dipelajari, sehingga individu mampu menemukan dan mengembangkan sendiri konsep, teori-teori dan prinsip-prinsip melalui contoh-contoh yang dijumpai dalam kehidupannya. ${ }^{47}$ Untuk meningkatkan proses belajar, menurut Bruner diperlukan lingkungan yang dinamakan "discovery learnig envoirment" atau lingkungan yang mendukung individu untuk melakukan eksplorasi dan penemuan-penemuan baru. ${ }^{48}$

Belajar penemuan (discovery learning) merupakan salah satu model pembelajaran atau belajar kognitif yang dikembangkan oleh Bruner. Menurut Bruner, belajar bermakna hanya dapat terjadi melalui belajar penemuan yang terjadi dalam proses belajar. ${ }^{49}$ Guru harus menciptakan situasi belajar yang problematis, menstimulus siswa dengan pertanyaanpertanyaan, mencari jawaban sendiri dan melakukan eksperimen. ${ }^{50}$ Bentuk lain dari belajar penemuan adalah guru menyajikan contoh-contoh dan siswa bekerja dengan contoh tersebut sampai dapat menemukan sendiri dan melakukan

${ }^{44}$ Al Rasyidin \& Wahyudin Nur Nasution, Teori Belajar dan Pembelajaran...., Op. Cit., h.

${ }^{45}$ C. Asri Budiningsih, Belajar dan Pembelajaran, (Jakarta: Rineka Cipta, 2005), Cet. 1, h.

41

${ }^{46}$ Slameto, Belajar dan Faktor-faktor yang Mempengaruhinya, (Jakarta: Rineka Cipta, 1995), h. 11

${ }^{47}$ Made Pidarta, Landasan Kependidikan: Stimulus Ilmu Pendidikan Bercorak Indonesia, (Jakarta: Rineka Cipta, 1997), h. 205

${ }^{48}$ Slameto, Belajar dan Faktor-faktor yang Mempengaruhinya, Loc. Cit.

49 Abu Ahmadi dan Joko Tri Prasetya, Strategi Belajar Mengajar, (Bandung : CV. Pustaka Setia, 2005), h. 76

${ }^{50}$ Ida Bagus Putrayasa, Landasan Pembelajaran (Bali: Undiksha Press, 2013), h. 66 
eksperiman. $^{51}$ Salah satu model belajar penemuan yang diterapkan di Indonesia adalah konsep yang kita kenal dengan Cara Belajar Siswa Aktif atau CBSA.

Dengan cara seperti ini, pengetahuan yang diperoleh oleh individu lebih bermakna baginya, lebih mudah diingat dan lebih mudah digunakan dalam pemecahan masalah. Dasar pemikiran teori ini memandang bahwa manusia sebagai pemeroses, pemikir dan pencipta informasi. ${ }^{52}$ Bruner menyatakan, belajar merupakan suatu proses aktif yang memungkinkan manusia untuk menemukan hal-hal baru di luar informasi yang diberikan kepada dirinya. ${ }^{53}$

2). Prinsip-prinsip Belajar menurut J. S. Bruner

Jerome S. Bruner adalah seorang ahli psikologi kognitif yang memberi dorongan agar pendidikan memberi perhatian pada pentingnya pengembangan kognitif. Bruner menjelaskan bahwa, belajar harus disesuaikan dengan tingkat perkembangan individu. Tingkat perkembangan individu menurut Bruner hampir sama dengan pendapat Piaget. Menurut Bruner, perkembangan intelektual anak dapat dibagi menjadi tiga, yaitu :

a). Fase pra-operasional, sampai usia 5-6 tahun, disebut masa pra sekolah. Pada taraf ini individu belum dapat mengadakan perbedaan yang tegas antara perasaan dan motif pribadinya dengan realitas dunia luar. Pada taraf ini kemungkinan untuk menyampaikan konsep-konsep tertentu kepada anak sangat terbatas. ${ }^{54}$ Tahap ini disebut juga dengan tahap enaktif, seseorang melakukan aktivitas-aktivitas dalam upayanya untuk memahami lingkungan sekitar atau dunia sekitarnya dengan menggunakan pengetahuan motorik. ${ }^{55}$ Misalnya, melalui gigitan, sentuhan, pegangan, dan sebagainya

b). Fase operasi kongkrit, pada taraf ke-2 ini operasi itu "internalized", artinya dalam menghadapi suatu masalah individu hanya dapat memecahkan masalah yang langsung dihadapinya secara nyata. Individu belum mampu memecahkan masalah yang tidak dihadapinya secara nyata atau kongkrit atau yang belum pernah dialami sebelumnya. ${ }^{56}$ Tahap ini disebut juga dengan tahap ikonik, seseorang memahami objek-objek atau dunianya melalui gambar-gambar atau visualisasi verbal. ${ }^{57}$ Maksudnya adalah dalam memahami dunia sekitarnya, anak belajar melalui perumpamaan atau tampil, gambar, visualisai dan perbandingan atau komparasi secara sederhana dan sebagainya..

\footnotetext{
${ }^{51}$ Ibid.

${ }^{52}$ Ratna Wilis Dahar, Teori-teori Belajar, (Jakarta: Direktorat P dan K, 1988), h. 118

${ }^{53}$ Bambang Warsita, Teknologi Pembelajaran Landasan dan Aplikasi, (Jakarta: Rineka Cipta, 2008), h. 91

${ }^{54}$ S. Nasution, Berbagai Pendekatan dalam Proses Belajar dan Mengajar, (Jakarta: Bumi Aksara, 2010), h. 7

${ }^{55}$ C. Asri Budiningsih, Belajar dan Pembelajara, Loc. Cit.

${ }^{56}$ S. Nasution, Berbagai Pendekatan dalam Proses Belajar dan Mengajar..., Loc. Cit.

${ }^{57}$ C. Asri Budiningsih, Belajar dan Pembelajaran..., Loc. Cit. 
c). Fase operasi formal, pada taraf ini anak itu telah sanggup beroperasi berdasarkan kemungkinan hipotesis dan tidak lagi dibatasi oleh apa yang berlangsung dihadapinya sebelumnya. ${ }^{58}$ Tahap ini disebut juga dengan tahap simbolik, seseorang telah mampu memilki ide-ide atau gagasan-gagasan abstrak yang sangat dipengaruhi oleh kemampuannya dalam berbahasa dan logika. ${ }^{59}$ Dalam memahami dunia sekitarnya anak belajar melalui simbol bahasa, logika, matematika dan sebagainya. Komunikasinya dilakukan dengan menggunakan banyak sistem simbol. Semakin matang seseorang dalam proses berpikirnya, semakin dominan sistem simbolnya. Meskipun begitu tidak berarti ia tidak lagi menggunakan sistem enaktif dan ikonik. Penggunaan media dalam kegiatan pembelajaran merupakan salah satu bukti masih diperlukannnya sistem enaktif dan ikonik dalam proses belajar.

3).Tahap-tahap dalam Proses Pembelajaran

Menurut Bruner, belajar pada dasarnya merupakan proses kognitif yang terjadi dalam diri seseorang. Ada 3 proses kognitif dalam belajar, yaitu:

a) Proses pemerolehan informasi baru.

b) Proses mentransformasikan informasi yang diterima.

c) Menguji atau mengevaluasi relevansi dan ketepatan pengetahuan. $^{60}$

Perolehan informasi baru dapat terjadi melalui kegiatan membaca, mendengarkan penjelasan guru mengenai materi yang diajarkan atau mendengarkan/melihat audiovisual dan lain-lain. Proses tranformasi yaitu tahap memahami, mencerna dan menganalisis pengetahuan baru serta mentransformasikan dalam bentuk baru yang mungkin bermanfaat untuk hal-hal yang lain. Tahap selanjutnya adalah menguji relevansi dan ketepatan pengetahuan atau informasi yang telah diterima tersebut atau mengetahui apakah hasil tranformasi pada tahap kedua benar atau tidak.

Menurut Bruner, ada beberapa hal yang perlu diperhatikan dalam pembelajaran agar pengetahuan dapat dengan mudah ditransformasikan, yaitu:

a) Struktur pengetahuan

Kurikulum harus berisikan struktur pengetahuan yang berisi berisi ide-ide, gagasan, konsep-konsep dasar, hubungan antara konsep atau contoh-contoh dari konsep yang dianggap penting. ${ }^{61}$ Hal ini sangat penting, sebab dengan adanya struktur pengetahuan akan membantu siswa untuk melihat bagaimana fakta-fakta yang kelihatannya tidak ada hubungan, dapat dihubungkan satu dengan yang lain, dan dengan informasi yang

${ }^{58}$ S. Nasution, Berbagai Pendekatan dalam Proses Belajar dan Mengajar..., Op. Cit., h. 8

${ }^{59}$ C. Asri Budiningsih, Belajar dan Pembelajara...., Loc. Cit.

${ }^{60}$ S. Nasution, Didaktik Asas-asas Mengajar, (Jakarta: Bumi Aksara, 1999), h. 48

${ }^{61}$ Ratna Wilis Dahar, Teori-teori Belajar...., Op. Cit., h. 119 
telah dimiliki oleh siswa. Agar dalam proses pembelajaran dapat berjalan efektif, sturuktur pengetahuan itu harus disesuaikan dengan karakteristik dan tingkat perkembangan anak.

b) Kesiapan belajar

Kesiapan belajar menurut Bruner, terdiri atas kesiapan yang berupa keterampilan yang sifatnya sederhana yang memungkinkan seseorang untuk menguasai keterampilan yang sifatnya lebih tinggi. ${ }^{62}$ Kesiapan belajar sangat dipengaruhi oleh kematangan psikologi dan pengalaman anak. Untuk mengetahui apakah siswa telah memiliki kesiapan dalam belajar, maka perlu diberi tes mengenai materi awal berdasarkan topik yang diajarkan.

c) Intuisi

Dalam proses belajar harus menekankan proses intuitif. Intuisi yang dimaksud Bruner adalah teknik-teknik intelektual untuk sampai pada formulasi tentatif tanpa melalui langkahlangkah analitis. ${ }^{63}$ Setiap disiplin ilmu mempunyai konsepkonsep, prinsip-prinsip dan prosedur yang harus dipahami sebelum seseorang mulai belajar. Cara terbaik untuk belajar adalah memahami konsep, arti dan hubungan melalui proses intuitif hingga akhirnya sampai pada satu kesimpulan atau menemukan sesuatu (discovery learning). ${ }^{64}$ Menurut $\mathrm{S}$. Nasution, berfikir intuitif hanya bisa berlangsung apabila seseorang memiliki ilmu yang luas tentang bidang ilmu itu dan memahami strukturnya. ${ }^{65}$

d) Motivasi

Motivasi adalah keadaan yang terdapat di dalam diri seseorang yang mendorong untuk melakukan aktifitas untuk mencapai tujuan tertentu. ${ }^{66}$ Dikaitkan dengan belajar, kondisi tertentu dapat mempengaruhi siswa untuk belajar, dan dapat pula membantu serta mendorong siswa mempunyai kemauan untuk belajar. Dalam belajar, siswa harus diberi motivasi dengan berbagai cara, sehingga muncul minat untuk belajar. ${ }^{67}$

4). Implikasi Teori Belajar Jerome Bruner dalam Pembelajaran

Pada prinsipnya teori Kognitif sebagaimana dikemukakan oleh Bruner merupakan pengembangan dari teori kognitif Piaget. Bruner lebih menekankan bagaiman mengeksplrorasi potensi yang dimiliki oleh individu. Ada beberapa hal yang sangat penting untuk

62 J. S. Bruner, Toward a Theory of Instruction, (New York: Nation, 1966), h. 29

63 Ratna Wilis Dahar, Teori-teori Belajar...., Loc. Cit.

64 Hamzah B. Uno, Orientasi Baru dalam Psikologi Pembelajaran, (Jakarta: Bumi Aksara, 2008), h. 91

${ }^{65}$ S. Nasution, Berbagai Pendekatan dalam Proses Belajar dan Mengajar ....., Op. Cit., h. 11

${ }^{66}$ Djaali, Psikologi Pendidikan, (Jakarta: Bumi Aksara, 2007), h. 101

${ }^{67}$ Lester D. Crow \& Alice Crow, Educational Psichologi: Psikologi Pendidikan: Buku I diterjemahkan oleh Z. Kasijan, (Surabaya: Bina Ilmu, 1984), h. 341 
diperhatikan dalam pembelajaran terkait dengan teori Kognitif Bruner, diantaranya adalah:

a). Partisipasi aktif individu dan mengenal perbedaan

Dalam proses pembelajaran harus menekankan pada cara individu mengorganisasikan apa yang telah dialami dan dipelajari. Sehingga dengan demikian individu mampu menemukan dan mengembangkan sendiri konsep, teori-teori dan prinsip-prinsip melalui contoh-contoh yang dijumpai dalam kehidupannya. Untuk mewujudkan hal tersebut, harus diciptakan lingkungan yang mendukung individu untuk melakukan eksplorasi dan menemukan gagasan-gagasan baru.

Oleh karena itu tujuan pembelajaran bukan sepenuhnya untuk memperoleh pengetahuan semata. Tetapi yang terpenting adalah melatih kemampuan intelek atau kognitif siswa, merangsang keinginan tahu, dan memotivasi siswa. Tujuan pembelajaran hanya diuraikan secara garis besar dan dapat dicapai dengan cara-cara yang tidak perlu sama oleh siswa yang mengikuti pelajaran yang sama. ${ }^{68}$ Atau dengan kata lain, tujuan pembelajaran hanya diuraikan secara garis besar. Untuk mendalami, merinci dan mempertajam tujuan pembelajaran tersebut diperlukan peran aktif siswa disesuaikan dengan potensi dan tingkat perkembangan siswa.

Walaupun demikian, pembelajaran terhadap individu tidak harus menunggu individu mencapai tahap perkembangan tertentu. Individu dapat mempelajari sesuatu meskipun umurnya belum memadai, asalkan materi pembelajaran disusun berdasarkan urutan isi dan disesuaikan dengan karakteristik kognitifnya.

b). Guru sebagai tutor, fasilitator, motivator dan evaluator

Menurut hemat penulis, dalam belajar penemuan (Discovery Learning), terjadi perubahan paradigma terhadap peran guru. Guru bukan lagi sebagai pusat pembelajaran, tetapi guru memiliki peran sebagai berikut :

(1). Merencanakan pelajaran demikian rupa sehingga pelajaran itu terpusat pada masalah-masalah yang tepat untuk diselidiki oleh para siswa.

(2). Menyajikan materi pelajaran yang diperlukan sebagai dasar bagi para siswa untuk memecahkan masalah. Materi pelajaran itu diarahkan pada pemecahan masalah yang aktif dan belajar penemuan. Guru mulai dengan sesuatu yang sudah dikenal oleh siswa-siswa. Kemudian guru mengemukakan sesuatu yang berlawanan. Dengan demikian terjadi konflik dengan pengalaman siswa. Akibatnya timbullah masalah. Dalam keadaan yang ideal, hal yang berlawanan itu menimbulkan suatu kesangsian yang merangsang para siswa untuk menyelidiki masalah

${ }^{68}$ J.S Bruner, Toward a Theory of Instruction ....., Op. Cit., h. 72 
itu, menyusun hipotesis-hipotesis, dan mencoba menemukan konsep-konsep atau prinsip-prinsip yang mendasari masalah itu. ${ }^{69}$

(3). Guru harus memperhatikan tiga cara penyajian, yaitu cara enaktif (melakukan aktifitas), cara ikonik (dengan gambar atau visualisasi), dan cara simbolik. Dengan kata lain, perkembangan kognitif individu dapat ditingkatkan dengan cara menata strategi pembelajaran sesuai dengan isi bahan akan dipelajari dan karakteristik kognitif individu.

(4). Bila siswa memecahkan masalah di laboratonium atau secara teoretis, guru berperan sebagai seorang pembimbing atau tutor. Guru jangan mengungkapkan terlebih dahulu prinsip atau aturan yang akan dipelajari, tetapi ia hendaknya rnemberikan saran-saran bilamana diperlukan. Sebagai seorang tutor, guru sebaiknya memberikan umpan balik pada waktu yang tepat. ${ }^{70}$ Umpan balik sebagai perbaikan hendaknya diberikan dengan cara demikian rupa, hingga siswa tidak tergantung pada pertolongan guru. Akhirnya siswa harus melakukan sendiri fungsi tutor itu.

(5). Pènilaian hasil belajar penemuan meliputi pemahaman tentang prinsip-prinsip dasar mengenai suatu bidang studi, dan kemampuan siswa untuk menerapkan prinsip-prinsip itu pada situasi baru. Untuk maksud ini bentuk tes dapat berupa tes objektif, tes essay, penilaian autentik dan penilaian performance. ${ }^{71}$

Dari uraian di atas, dapat diketahui bahwa guru berperan sebagai tutor, fasilitator, motivator dan evaluator. Dengan kata lain, guru tidak harus mengendalikan proses pembelajaran. Guru hendaknya mengarahkan pelajaran pada penemuan dan pemecahan masalah. Penilaian hasil belajar meliputi tentang konsep dasar dan penerapannya pada situasi yang baru.

Selain itu, dalam belajar penemuan, teman dan siswa memiliki perang yang sangat penting. Sebagaimana diuraikan di atas, dalam teori Bruner, lebih menekankan agar siswa

${ }^{69}$ Ratnawilis Dahar, Teori-teori Belajar.....,Op. Cit., h. 131

${ }^{70}$ Ibid.

${ }^{71}$ Tes objektif adalah tes yang disusun sedemikian rupa dan telah disediakan alternatif jawabannya. Tes essay adalah tes yang disusun dalam bentuk pertanyaan/pernyataan bebas atau terstruktur, kemudian peserta didik menyusun dan mengorganisasikan sendiri jawaban tiap pertanyaan/pernyataan tersebut dengan bahasa sendiri. Penilaian autentik adalah penilaian yang menuntuk siswa untuk melakukan, menarapkan atau melaksanakan suatu tugas dalam kehidupan nyata. Penilaian performance adalah penilaian yang menuntut siswa untuk mengungkapkan kemampuan, keterampilan dan sikap yang dimiliki secara menyeluruh. Keempat jenis tes itu (tes objektif, tes essay, penilaian autentik dan penilaian performance) sangat baik digunakan untuk menilai hasil belajar siswa di sekolah guna mengetahui apakan tujuan yang digariskan tercapai atau belum. Dapat di lihat pada, A.Muri Yusuf, Asesement dan Evaluasi Pendidikan: Pilar Penyedia Informasi dan Kegiatan Pengendalian Mutu Pendidikan, (Padang: UNP Press, 2011), h. 102, 313 dan 3.17. 
berperan aktif dalam proses pembelajaran, dan memberikan kesempatan kepada siwa untuk menemukan suatu konsep, teori, aturan, atau pemahaman melalui contoh-contoh yang dijumpai dalam kehidupannya. Oleh karena itu, guru harus mengupayakan agar setiap siswa berpartisipasi aktif, motivasi dan minatnya perlu ditingkatkan, kemudian perlu dibimbing untuk mencapai tujuan tertentu. ${ }^{72}$ Dalam proses pembelajaran, siswa dapat saling bertukar informasi terhadap apa yang dipelajari dan ditemukan sendiri. Untuk mengoptimalkan proses pembelajaran penemuan ini, teori ini dapat juga disajikan dalam bentuk diskusi kelas, demonstrasi, kegiatan laboratorium, kertas kerja siswa, dan evaluasi-evaluasi. ${ }^{73}$

Pada diskusi, guru harus merumuskan lebih dahulu yang akan dicapai, mengenai konsep-konsep, prinsip-prinsip atau kemampuan apa saja yang dapat dikembangkan siswa. Prinsipprinsip itu diusahakan tersaji dalam bentuk masalah. Siswa diharapkan dapat merumuskan, mengolah, kemudian memecahkannya, sehingga dapat menemukan sendiri konsepkonsep atau prinsip-prinsip sesuai dengan yang telah direncanakan guru.

c. Teori Belajar Ausubel: Belajar Bermakna

Menurut Ausubel belajar haruslah bermakna. Materi yang dipelajari diasimilasikan secara non arbitrer dan berhubungan dengan pengetahuan yang telah dimiliki sebelumnya. ${ }^{74}$ Ausubel seorang psikologist kognitif, ia mengemukakan bahwa yang perlu diperhatikan seorang guru ialah strategi mengajarnya. Contoh pelajaran berhitung bisa menjadi tidak berhasil jika siswa hanya disuruh menghafal formula-formula tanpa mengetahui arti formula-formula itu. Sebaliknya bisa lebih bermakna jika murid diajari fungsi dan arti dari formula-formula tersebut. ${ }^{75}$

1). Belajar menurut Teori Ausubel

Menurut Ausubel, belajar dapat dilkasifikasikan ke dalam dua dimensi. Dimensi pertama, berhubungan dengan cara informasi atau materi pelajaran disajikan pada siswa, melalui penerimaan atau penemuan. ${ }^{76}$ Dimensi kedua, menyangkut cara bagaimana siswa dapat mengaitkan informasi itu pada struktur kognitif yang ada. ${ }^{77}$ Struktur kognitif tersebut mencakup faktafakta, konsep-konsep dan generalisasi-generalisasi yang telah dipelajari dan diinginkan oleh siswa.

Pada tingkat pertama dalam belajar, informasi dapat dikomunikasikan kepada siswa baik dalam bentuk belajar

\footnotetext{
${ }^{72}$ Slameto, Belajar dan Faktor-Faktor yang Mempengaruhinya..., Op. Cit., h. 12

${ }_{73}$ Abu Ahmadi dan Joko Tri Prasetya, Strategi Belajar Mengajar...., Op. Cit., h. 78

${ }^{74}$ Al Rasyidin \& Wahyudin Nur Nasution,Teori Belajar dan Pembelajaran...., Op. Cit., h. 35

${ }^{75}$ Abu Ahmad \& Widodo Aupriyono,Psikologi Belajar....., Op. Cit., h. 220

${ }^{76}$ Ratna Wilis Dahar, Teori-teori Belajar...., Op. Cit.,h. 134

${ }^{77}$ Ibid.
} 
penerimaan yang manyajikan informasi secara final, maupun dalam bentuk belajar penemuan yang mengharuskan siswa menemukan sendiri sebagian atau seluruh materi yang akan diajarkan. Pada tingkat kedua, siswa menghubungkan atau mengaitkan informasi baru dengan struktur pengetahuan (fakta, konsep-konsep, generalisasi dan lainnya) yang dimiliki oleh siswa, dalam hal ini terjadi belajar bermakna (meaningful learning). ${ }^{78}$ Akan tetapi, siswa dapat juga berusaha mencoba-coba menerima, menguasai dan menghafal informasi baru itu tanpa menghubungkan dengan konsep-konsep yang ada dalam kognitifnya, maka terjadilah belejar hafalan ((rote learning $))^{79}$

Kedua dimensi tersebut, (penerimaan/penemuan dan bermakna/hafalan) tidak menunjukkan dikotomi, melainkan menunjukkan kontinum. Kedua kontinum tersebut dapat dilihat gambar di bawah ini :

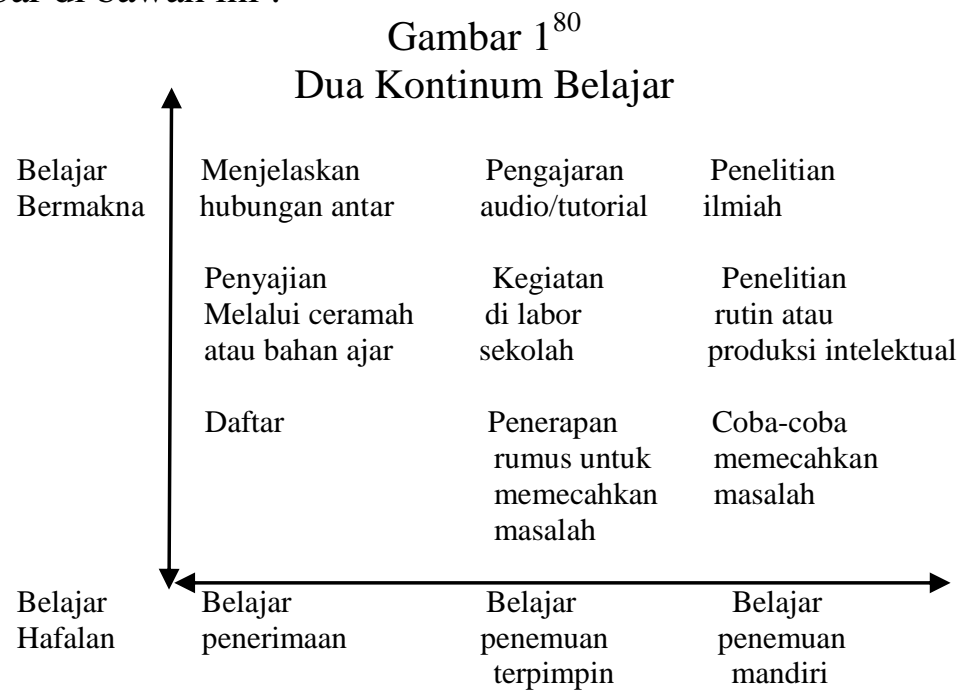

Pada kontinum mendatar dalam gambar di atas menunjukkan bahwa, dari kiri ke kanan semakin berkurangnya belajar menerima, dan bertambahnya belajar penemuan. Sedangkan pada kontinum vertikal, dari bawah ke atas berkurangnya belajar hafalan dan bertambahnya belajar bermakna. Menurut teori Ausubel, belajar dengan cara menerima informasi dapat dibuat bermakna apabila dijelaskan, kemudian dihubungkan antara konsep yang satu dengan yang lainnnya. Begitu sebaliknya, belajar penemuan (termasuk penemuan mandiri) akan kurang bermakna apabila hanya dilakukan dengan hafalan (coba-coba).

2). Faktor-faktor dan Syarat Belajar menurut Ausubel

Ada beberapa faktor yang dapat mempengaruhi belajar bermakna, yaitu struktur kognitif yang ada, stabilitas dan kejelasan

${ }^{78}$ Winfred F. Hill, Theories of Learning (Teori-teori dalam Pembelajaran,Konsepsi, Komparasi, dan Signifikan), (Bandung: Nusa Media, 2011), h. 160-161.

${ }^{79}$ Ibid.

${ }^{80}$ J.D Noval and D.B. Gowin, Learning ow to Learn Cambridge, (Cambridge University Press, 1985), h. 82 
pengetahuan. ${ }^{81}$ Semakin bagus dan stabil struktur kognitif serta semakin jelas pengetahuan atau informasi baru masuk ke dalam struktur kognitif, maka akan semakin mudah terjadinya proses belajar bermakna, begitu juga sebaliknya. Di samping itu, ada persyaratan yang harus dipenuhi dalam berlajar bermakna, yaitu:

Pertama, materi yang akan dipelajari harus bermakna secara potensial. Materi pelajaran dikatakan bermakna secara potensial apabila materi tersebut logis dan relevan dengan struktur kognitif siswa. Materi dikatakan logis apabila materi tersebut konsisten dengan apa yang telah diketahui oleh siswa, dan dapat dinyatakan dengan berbagai cara tanpa mengubah makna. Materi dikatakan sesuai dengan struktur kognitif siswa apabila sesuai dengan pengalaman, tingkat perkembangan, intelegensi dan usia siswa. ${ }^{82}$ Kedua, Siswa yang akan belajar harus bertujuan untuk melaksanakan belajar bermakna, (memiliki kesiapan dan minat untuk belajar bermakna). ${ }^{83}$ Dari kedua syarat ini, tujuan siswa merupakan hal yang sangat penting dalam belajar bermakna. Apabila siswa memiliki tujuan, dalam arti memiliki kesiapan dan minat untuk belajar mermakna, maka akan dengan mudah proses belajar bermakna dilaksanakan.

Agar pembelajaran menjadi bermakna, ada beberapa hal yang harus dilakukan oleh guru, yaitu :

a). Pengaturan awal (advance organizer). Pengaturan awal ini bertujuan untuk mengarahkan siswa ke matei yang akan dipelajari dan menolong siswa mengaitkan dengan materi yang telah dipelajari.

b). Diferensial progresif, yaitu pengembangan dan elaborasi konsep-konsep yang tersubsumsi. Cara yang paling baik adalah bila unsur-unsur yang paling umum dan iklusif diperkenalkan terlebih dahulu, kemudian diberikan hal-hal yang lebeih mendetail. Hal ini misalnya, dapat dilakukan peta konsep.

c). Belajar superordinat, yaitu suatu proses belajar yang merangsang terjadinya perubahan struktor kognitif ke arah defensiasi sehingga menemukan hal-hal yang baru.

d). Penyesuaian integratif, yaitu membandingkan, mempertentangkan dan menghubungkan konsep baru dengan konsep sebelumnya, atau dengan konsep-konsep yang lebih tinggi lainnya. ${ }^{84}$

3). Implikasi Teori Belajar Ausubel dalam Pembelajaran

Dari uraian tentang teori Ausubel di atas dapat diambil bebarapa catatan penting terkait dengan pembelajaran, diantaranya adalah :

\footnotetext{
${ }^{81}$ Ratnawilis Dahar, Teori-teori Belajar...., Op. Cit.,h. 141

${ }^{82}$ Nana Syaodih dan Sukmadinata, Landasan Psikologi Proses Pendidikan, Cet. IV, (Bandung: Remaja Rosdakarya, 2007), h. 188

${ }^{83}$ Ratna Wilis Dahar, Teori-teori Belajar...., Op.Cit., h. 142

${ }^{84}$ Ibid, h. 144-148
} 
a) Kunci keberhasilan dalam belajar terletak pada kebermaknaan bahan ajar yang diterima atau yang dipelajari oleh siswa.

Oleh karena itu dalam proses pembelajaran guru harus mampun memberikan sesuatu yang bermakna bagi siswa. Sesuatu yang bermakna itu bukan hanya dapat diperoleh melalui belajar penemuan, tetapi dapat diperoleh melalui banyak cara. Belajar dengan menghafal dan ceramah pun dapat menemukan sesuatu yang bermakna, asal dilakukan secara sistematis, menjelaskan dan menghubungkan antara konsep yang satu dengan konsep lainnya, menguhubungkan konsep yang baru dengan konsep yang telah dimiliki oleh siswa. Sebaliknya, belajar penemuan akan menjadi kurang bermakna, apa bila dilakukan dengan coba-coba dan tidak sistematis.

Untuk mewujudkan pembelajaran yang bermakna ini, guru sangat dituntut untuk mempu menggali dan mengeksplorasi segala potensi yang dimiliki oleh siswa dengan berbagai macam strategi, model, metode dan pendekatan pembelajaran. Sehingga siswa terbantu dalam memperoleh informasi, ide, keterampilan, cara berfikir dan mengekspresikan dirinya guna memendapatkan sesuatu yang bermakna dari proses pembelajaran.

b) Belajar bermakna akan berhasil apabila ada motivasi intrinsik dari dalam diri siswa

Menurut Ausubel, belajar bermakna akan terjadi apabila siswa memiliki minat dan kesiapan untuk belajar. Minat dan kesiapan erat kaitannya dengan motivasi. Motivasi menurut M. Ngalim Purwanto merupakan dorongan yang menggerakkan individu untuk bertingkahlaku. ${ }^{85}$ Motivasi yang terpenting adalah motivasi intrinsik, yaitu motivasi yang datang dari dalam diri individu. Dengan adanya motivasi intrinsik ini akan menumbuhkan minat dalam diri individu, dan menggerakkan individu untuk mempersiapkan diri untuk belajar, baik mempersiapkan diri secara fisik maupun psikis.

Motivasi intrinsik ini sesungguhnya dapat dibetuk melalui motivasi ekstrinsik, yaitu motivasi yang datang dari luar diri individu. Seperti dorongan dari orang tua, guru, teman dan sebagainya. Oleh karena itu, guru dan orang tua memiliki peran yang sangat penting dalam menumbuhkan motivasi intrinsik dalam diri siswa. Dorongan, perhatian dan kasih sayang orang tua dan guru merupakan salah satu faktor yang akan menumbuhkan motivasi intrinsik dalam diri sisiwa terkait dengan belajar.

d. Teori Belajar Gestalt

Kata Gestalt berasal dari bahasa Jerman yang mempunyai padanan makna sebagi "bentuk atau konfigurasi". ${ }^{86}$ Inti dari belajar

${ }^{85}$ M. Ngalim Purwanto, Psikologi Pendidikan....., Op. Cit., h. 60

${ }^{86}$ Mohammad Jauhar, Implementasi PAIKEM dari Behaviorisme sampai Kontruktivistik: Sebuah Pengembangan Pembelajaran Berbasis CTL, (Jakarta: Prestasi Pustaka, 2011), h. 26 
menurut Gestalt bahwa objek atau peristiwa tertentu dipandang sebagai suatu keseluruhan yang terorganisir. Teori Gestalt dirintis oleh Chr. Von Ehrenfels dengan karyanya "Uber Destaltqualitation" pada tahun 1890, kemudian dikembangkan oleh Koffka, Kohler, dan Wertheimer. ${ }^{87}$ Teori belajar Gestal disebut juga dengan feld theory atau insight full learning. ${ }^{88}$

\section{1). Belajar menurut Gestal}

Menurut teori Gestalt belajar adalah proses pengembangan yang didasarkan pada pemahaman atau insight. ${ }^{89}$ Insight adalah pemahaman terhadap hubungan antar bagian dalam suatu situasi permasalahan. Teori Gestalt menganggap bahwa insight adalah inti dari pembentukan tingkah laku. ${ }^{90}$ Teori belajar Gestalt pada dasarnya sebagai usaha untuk memperbaiki proses belajar dengan rote learning dengan pengertian bukan menghapal. ${ }^{91}$ Dalam belajar, menurut teori Gestalt, yang terpenting adalah penyesuaian pertama, yaitu mendapatkan respons atau tanggapan yang tepat. Belajar yang terpenting bukan mengulangi hal-hal yang harus dipelajari, tetapi mengerti atau memperoleh insight. Belajar dengan pengertian lebih dipentingkan daripada hanya memasukkan sejumlah kesan. Belajar dengan insight adalah sebagai berikut :

a) Insight tergantungg dari kemampuan dasar;

b) Insight tergantung dari pengalaman masa lampau yang relevan;

c) Insight hanya timbul apabila situasi belajar diatur sedemikian rupa, sehingga segala aspek yang perlu dapat diamati;

d) Insight adalah hal yang harus dicari, tidak dapat jatuh dari langit;

e) Belajar dengan insight dapat diulangi;

f) Insight sekali didapat dapat digunakan untuk menghadapi situasi-situasi baru.

Keterlibatan seseorang secara langsung dalam situasi belajar sangat penting. Keterlibatan dalam belajar akan menghasilkan pemahaman (insinght) yang dapat membantu individu dalam proses belajar. Dengan kata lain, yang terpenting dalam belajar menurut teori Gestalt adalah dimengertinya apa yang dipelajari oleh individu tersebut.

2). Prinsip-prinsip Belajar menurut Teori Gestalt

Ada bebepara prinsip dalam belajar menurut teori Gestal, yaitu :

${ }^{87}$ Ibid.

${ }^{88}$ M. Ngalim Purwanto, Psikologi Pendidikan ...., Op. Cit., h. 100

${ }^{89}$ Baharuddin dan Esa Nur Wahyuni, Teori Belajar dan Pembelajaran, (Jakarta: Ar Ruzz Media, 2010), h. 88

${ }^{90}$ Ibid.

${ }^{91}$ Yatim Riyanto, Paradigma Baru Pembelajaran: Sebagai Referensi bagi Guru/Pendidik dalam Implementasi Pembelajaran yang Efektif dan Berkualitas, (Jakarta: Kencana, 2010), h. 84

${ }^{92}$ Syaiful Bahri Djamarah, Psikologi Belajar, (Jakarta: Rineka Cipta, 2002), h. 19 
a) Tujuan belajar adalah untuk mendapatkan pemahaman atau insight

b) Belajar dimulai dari keseluruhan. Keseluruhan yang menjadi permulaan, baru menuju ke bagian-bagian. Keseluruhan memberikan makna kepada bagian-bagian.

c) Individuasi bagian-bagian dari keseluruhan. Mula-mula anak melihat sesuatu sebagai keseluruhan. Bagian-bagian dilihat dalam hubungan fungsional dengan keseluruhan. Tetapi lambat laun ia mengadakan deferensiasi bagian-bagian itu dari keseluruhan menjadi bagian-bagian yang lebih kecil atau kesatuan yang lebih kecil.

d) Individu belajar dengan menggunakan pemahaman atau insight. Memahami sesuatu dapat dilakukan dengan melihat hubungan-hubungan antara berbagai faktor atau unsur dalam situasi yang problematik, dan kemampuan menghubungkan pengetahuan yang baru dengan pengetahuan sebelumnya. ${ }^{93}$

Dengan kata lain, belajar akan terjadi apabila ada pengertian atau insight. Pengertian atau insight muncul apabila seseorang telah memahami suatu masalah atau informasi, kemudian kejelasan, kemudian melihat hubungan unsur yang satu dengan yang lainnya, dipahami sangkut-pautnya dan dimengerti maknanya. Belajar juga erat kaitananya antara penemuanpenemuan baru dengan pengalaman-pengalaman yang sudah ada. Oleh karena itu, agar siswa mudah mendapatkan pengalaman baru, maka siswa harus dipancing dengan pengalamanpengalaman yang ada. Individu memahami sesuatu dengan cara mengatur dan menyusun kembali pengalaman-pengalamannya yang banyak dan berserakan menjadi satu struktur yang memiliki makna dan dapat dipahami olehnya.

3). Implikasi Teori Gestal dalam Pembelajaran

Berdasarkan beberapa pokok pikiran terkait dengan teori belajara Gestal, ada beberapa hal yang dapat diterapkan dalam proses pembelajaran, diantaranya adalah:

a) Perilaku bertujuan. Belajar harus terarah pada tujuan. Belajar bukan hanya terjadi akibat hubungan stimulus-respons, tetapi ada keterkaitannya dengan tujuan yang ingin dicapai, yaitu untuk mendapatkan pemahaman tentang sesuatu. Proses pembelajaran akan berjalan efektif jika siswa mengenal tujuan yang ingin dicapainya. Oleh karena itu, guru harus menyadari tujuan sebagai arah aktivitas pengajaran dan membantu peserta didik dalam memahami tujuannya.

b) Pembelajaran akan bermakna apabila siswa mampu memahami secara totalitas terhadap objek yang dipelajari, memiliki kemampuan mengenal dan memahami unsur-unsur, mampu memahami keterkaitan unsur-unsur dalam suatu obyek atau

${ }^{93}$ Sumardi Suryabrata, Psikologi Pendidikan, (Jakarta : PT. Raja Grafindo Persada, 2006), h. 279 
peristiwa, dan keterkaitan antara pengetahuan yang baru dengan pengetahuan sebelumnya.

\section{Penutup.}

Bedasarkan uraian sebagaimana dikemukakan di atas, dapat ditarik beberapa catatan penting, yaitu :

1. Dari teori kognitif sebagaimana dikemukakan oleh Piaget setidaknya ada dua hal penting yang dapat diambil, yaitu : Pertama, individu dapat mengembangkan pengetahuannya sendiri. Artinya adalah pengetahuan yang dimiliki oleh setiap individu dapat dibentuk oleh individu sendiri melalui interaksi dengan lingkungan yang terus-menerus dan selalu berubah. Dalam berinteraksi dengan lingkungan, individu mampu beradaptasi dan mengorganisasikan lingkungannya, sehingga terjadi perubahan dalam struktur kognitifnya, pengetahuan, wawasannya dan pemahamannya semakin berkembang. Individu juga mampu memodivikasi pengalaman yang diperoleh melalui lingkungan, sehingga melahirkan pengetahuan atau temuan-temuan baru. Oleh karena itu, proses pendidikan bukan hanya sekedar transfer of knowledge, tetapi juga bagaimana merangsang struktur kognitif inadividu mampu melahirkan pengetahuan dan temuan-temuan baru. Kedua, perlu adanya individualisasi dalam pembelajaran. Artinya, dalam proses pembelajaran, perlakuan terhadap individu harus didasarkan pada perkembangan kognitifnya. Setiap tahap perkembangan kognitif memiliki karakteristik berbeda-beda. Susunan saraf seorang akan semakin kompleks seiring dengan bertambahnya umur. Belajar akan lebih berhasil apabila disesuaikan dengan tahap perkembangan kognitif peserta didik.

2. Berkaitan dengan teori belajar J.S. Bruner, ada beberapa hal penting yang harus diperhatikan dalam pembelejaran, Pertama, dalam pembelajaran harus ada partisipasi aktif individu dan mengenal perbedaan. Pembelajaran harus menekankan pada cara individu mengorganisasikan apa yang telah dialami dan dipelajari. Individu diberi kesempatan seluasluasnya untuk menemukan dan mengembangkan sendiri konsep, teori-teori dan prinsip-prinsip melalui contoh-contoh yang dijumpai dalam kehidupannya. Oleh karena itu, sekolah harus diciptakan lingkungan yang mendukung individu untuk melakukan eksplorasi dan menemukan gagasan-gagasan baru. Kedua, guru dalam proses pembelajaran perperan sebagai tutor, fasilitator, motivator dan evaluator. Dengan kata lain, guru tidak begitu mengendalikan proses pembelajaran. Guru hendaknya mengarahkan pelajaran pada penemuan dan pemecahan masalah. Penilaian hasil belajar meliputi tentang konsep dasar dan penerapannya pada situasi yang baru.

3. Setidaknya ada dua hal penting yang dapat diambil dari teori belajar Ausubel, Pertama, kunci keberhasilan dalam belajar terletak pada kebermaknaan bahan ajar yang diterima atau yang dipelajari oleh siswa. Dalam proses pembelajaran guru harus mampun memberikan sesuatu yang bermakna bagi siswa. Belajar dengan menghafal dan ceramah dapat menemukan sesuatu yang bermakna, asal dilakukan secara sistematis, menjelaskan dan menghubungkan antara konsep yang satu dengan konsep 
lainnya, menguhubungkan konsep yang baru dengan konsep yang telah dimiliki oleh siswa. Sebaliknya, belajar penemuan akan menjadi kurang bermakna, apa bila dilakukan dengan coba-coba dan tidak sistematis. Kedua, belajar bermakna akan berhasil apabila ada motivasi intrinsik dari dalam diri siswa. Dengan adanya motivasi intrinsik ini akan menumbuhkan minat dalam diri individu, dan menggerakkan individu untuk mempersiapkan diri untuk belajar, baik mempersiapkan diri secara fisik maupun psikis.

4. Beberapa hal penting yang dapat diambil dari teori belajar Gestal, Pertama, tujuan utama belajar adalah untuk memperoleh pemahaman tentang sesuatu. Kedua, pembelajaran akan bermakna apabila siswa mampu memahami objek pembelajaran secara totalitas, memahami unsurunsur objek yang dipelajari, mampu mecari hubungan antara satu unsur dengan unsur lainnya, dan mampu menghubungkan pengetahuan yang baru dengan pengetahuan sebelumnya. 


\section{DAFTAR PUSTAKA}

Abu Ahmadi dan Joko Tri Prasetya, 2005, Strategi Belajar Mengajar, Bandung : CV. Pustaka Setia Cipta ,dan Widodo Supriyono, 1991, Psikologi Belajar, Jakarta : Rineka dan Munawar Sholeh, 2005, Psikologi Perkembangan, Jakarta : Rineka Cipta

Agus Suyanto, 1990, Psikologi Perkembangan, Jakarta: PT. Aksara Baru

Ahmad Muzakir dan Joko Sutrisno, 1997, Psikologi Pendidikan: untuk Fakultas Tarbuyah Komponen MKBK, Jakarta: Pustaka Setia

A. Muri Yusuf, 2011, Asesement dan Evaluasi Pendidikan: Pilar Penyedia Informasi dan Kegiatan Pengendalian Mutu Pendidikan, Padang: UNP Press

Al Rasyidin \& Wahyudin Nur Nasution, 2011, Teori Belajar dan Pembelajaran, Medan : Perdana Publishing

Baharuddin dan Esa Nur Wahyuni, 2011, Teori Belajar dan Pembelajaran, Jakarta: Ar Ruzz Media

Bambang Warsita, 2008, Teknologi Pembelajaran Landasan dan Aplikasi, Jakarta: Rineka Cipta

Bruner, J.S, 1966, Toward a Theory of Instruction, New York: Nation

C. Asri Budiningsih, 2005, Belajar dan Pembelajaran, Jakarta: Rineka Cipta

Crow, Lester \& Alice Crow, 1984, Educational Psichologi: Psikologi Pendidikan: Buku I diterjemahkan oleh Z. Kasijan, Surabaya: Bina Ilmu

Departemen Pendidikan dan Kebudayaan, 2002, Kamus Besar Bahasa Indonesia, Jakarta: Balai Pustaka

Desmita, 2008, Psikologi Perkembangan, Bandung: PT. Remaja Rosdakarya

Dewi Purnama Sari, 2010, Psikologi Perkembangan Anak, Curup: LP2 STAIN Curup

Dimyati dan Muljiono, 2006, Belajar dan Pembelajaran, Jakarta: Rineka Cipta

Djaali, 2007, Psikologi Pendidikan, Jakarta: Bumi Aksara 
Elida Prayitno, 1991, Perkembangan Peserta Didik, Jakarta : Dirjen Dikti

Endang Purwanti Nur Widodo, 2005, Perkembangan Peserta Didik, Malang: UMM Press

Fauziah Nasution, 2011, Psikologi Umum: Buku Panduan untuk Fakultas Tarbiyah, Medan: IAIN SU Press

F.Hill, Winfred, 2011, Theories of Learning (Teori-teori dalam Pembelajaran, Konsepsi, Komparasi, dan Signifikan, Bandung: Nusa Media

Gredler, Margaret \& E. Bell, 1991, Learning And Instruction Theory Into Practice. Mc.-Mi-lan Publishing Company. Diterjemah-kan oleh Munandir, Jakarta: Rajawali

Hamzah B. Uno, 2008, Orientasi Baru dalam Psikologi Pembelajaran, Jakarta: Bumi Aksara

Haryanto Suyono, 2011, Belajar dan Pembelajaran, Bandung: Remaja Rosdakarya

Hartono. A dan Sunarto, 1992, Perkembangan Peserta Didik, Jakarta: Direktorat Jendral Pendidikan Tinggi, Depdikbud

Hendra Harmi, 2010, Teori Belajar dan Pembelajaran, Curup: LP2 STAIN

Hurlock, Elizabet. B, 1992, Psikologi Perkembangan: Suatu Pendekatan Sepanjang Rentang Kehidupan Manusia, Jakarta: Erlangga

Ida Bagus Putrayasa, 2013, Landasan Pembelajaran Bali: Undiksha Press

Kartini Kartono, 1995, Psikologi Anak (Psikologi Perkembangan), Bandung: Mondar Maju

Made Pidarta, 1997, Landasan Kependidikan: Stimulus Ilmu Pendidikan Bercorak Indonesia, Jakarta: Rineka Cipta

Mimi Suharti, 2011, Perkembangan Peserta Didik, Padang: IAIN IB Press

Mohammad Jauhar, 2011, Implementasi PAIKEM dari Behaviorisme sampai Kontruktivistik: Sebuah Pengembangan Pembelajaran Berbasis CTL, Jakarta: Prestasi Pustaka

M. Ngalim Purwanto, 2004, Psikologi Pendidikan, Bandung: PT. Remaja Rosdakarya

Muhaimin, 2012, Paradigma Pendidikan Islam: Upaya Mengefektifkan Pendidkan Agama Islam di Sekolah, Bandung: PT. Remaja Rosdakarya 
Mulyono Abdurrahman, 2003, Pendidikan bagi Anak Berkesulitan Belajar, Jakarta: Rineka Cipta

Muhibbin Syah, 2010, Psikologi Pendidikan: Suatu Pendekatan Baru, Bandung: Remaja Rosdakarya

Mustakim dan Abdul Wahab, 2003, Psikologi Pendidikan, Jakarta: Rineka Cipta

Nana Syaodih dan Sukmadinata, 2007, Landasan Psikologi Proses Pendidikan, Cet. IV, Bandung: Remaja Rosdakarya

Noval, J.D and D.B. Gowin, 1985, Learning ow to Learn Cambridge, Cambridge University Press

Ratna Wilis Dahar, 1988, Teori-teori Belajar, Jakarta: Direktorat P dan K

Santrock, J.W, 2004, Perkembangan Masa Hidup Jilid I, Jakarta, Erlangga

Sjarkawi, 2006, Pembentukan Kepribadian Anak: Peran Moral, Intelektual dan Sosial sebagai Wujud Integritas Membangun Jati Diri, Jakarta: Bumi Aksara

Slameto, 1995, Belajar dan Faktor-faktor yang Mempengaruhinya, Jakarta: Rineka Cipta

S. Nasution, 2010, Berbagai Pendekatan dalam Proses Belajar dan Mengajar, Jakarta: Bumi Aksara , 1999, Didaktik Asas-asas Mengajar, Jakarta: Bumi Aksara

Slaven, Robert. E, 2011, Educational Psycology: Theory and Practice. (America: The United States of America

Sumardi Suryabrata, 2006, Psikologi Pendidikan, Jakarta : PT. Raja Grafindo Persada

Syaiful Bahri Djamarah, 2002, Psikologi Belajar, Jakarta: Rineka Cipta

Syamsu Yusuf LN, 2008, Psikologi Perkembangan Anak dan Remaja, Jakarta, Remaja Rosdakarya

Trianto, 2007, Model Pembelajaran Terpadu dalam Teori dan Praktek, Jakarta: Prestasi Pustaka Publisher

Westy Soemanto. 2003, Psikologi Pendidikan, Jakarta : Rineka Cipta

Wingkel, WS, 1996, Psikologi Pendidikan, Jakarta: Gramedia 
Yatim Riyanto, 201, Paradigma Baru Pembelajaran: Sebagai Referensi bagi Guru/Pendidik dalam Implementasi Pembelajaran yang Efektif dan Berkualitas, Jakarta: Kencana

Yusuf, dkk, 1993, Konsep Dasar dan Pengelolaan Kegiatan Belajar Mengajar, Bandung: Andira 